Association for Information Systems

AIS Electronic Library (AISeL)

ICEB 2003 Proceedings

International Conference on Electronic Business

(ICEB)

Winter 12-9-2003

\title{
Transcending the Digital Divide: Paving Itinerary for Conducive Digital Economy
}

Kapil Mohan Garg

Nikhil Agarwal

A.M Sherry

Follow this and additional works at: https://aisel.aisnet.org/iceb2003

This material is brought to you by the International Conference on Electronic Business (ICEB) at AIS Electronic Library (AISeL). It has been accepted for inclusion in ICEB 2003 Proceedings by an authorized administrator of AIS Electronic Library (AISeL). For more information, please contact elibrary@aisnet.org. 


\title{
Transcending the Digital Divide: Paving Itinerary for Conducive Digital Economy
}

\author{
Kapil Mohan Garg, \\ Nikhil Agarwal, \\ Research Fellow, \\ Research Fellow, \\ A.M Sherry \\ Professor, \\ Institute of Management Technology Institute of Management Technology Institute of Management Technology \\ India \\ India \\ kapil@imt.ac.in \\ nikhil@imt.ac.in \\ India
sherry@imt.ac.in
}

\begin{abstract}
$\underline{\text { Abstract }}$
In recent years, due to dynamic evolution of information and communication technologies (ICTs) and the increasing importance of ICT diffusion in the process of economic growth, there exists the need for a broad and systematic comparison of the ICT framework development of countries around the globe. The Information Age that is upon us holds out the promise of a new world of shared prosperity, a global renaissance. At the same time, it also holds out the danger of economic exploitation, societal devastation and a new era of imperialism and colonialism. It can be spurned if we can bridge the economic and development gap, the information and knowledge gap and the great divide within.

A key element to extending the information revolution is identification, development and utilization of information assets. Information and knowledge is the new fuel of the economy. In this information economy, economic development means harnessing the information and knowledge assets of a community to help local businesses succeed in the new environment.
\end{abstract}

\section{Introduction}

There are many economic, political and cultural issues wrapped up in the digital divide. The facts suggests that there is a wide gap in computer use between rich and poor countries, and between rich and poor within most countries, and this gap often is a reflection of religious, ethnic and racial distinctions that shadow economic divisions throughout the world.

This gap, the "digital divide", threatens to cut off populations and seize the chance to participate in the affairs of the broader society. For some citizens technology brings the promise of inclusion, opportunity and wealth; for others, greater isolation and increased poverty. Herein lays the present tragedy and the making of a future catastrophe. It urges the important need to probe relationships between the public, corporate, and nonprofit sectors to address the critical questions for democracy in the information age.

The task is not just about reviving the weak economy. Real sustainable economic growth will come from expanding the information revolution to all parts of society. It is evident that the value of a network increases exponentially in relation to the number of users and the same is true for markets and economic activity. By leaving some behind, we impoverish not only those individuals; we also impoverish ourselves.
Local knowledge and information assets can be drivers of that economic development activity by:

- Capturing and using that knowledge as an information product;

- Using local knowledge to identify new entrepreneurial opportunities; and

- Developing the local knowledge and social capital base to facilitate innovation.

There is a need to work on narrowing the digital divide as much as possible by allowing all to exploit the Internet revolution, with elaborate global coordination and cooperation. This paper focuses on the subjects that are responsible for this divide and possible renaissance of improved information society. The Internet may follow a pattern similar to the telecommunications revolution of the 19th and 20th centuries. The last decade has seen the developed countries benefit from the Internet far more than the emerging countries. Countries such as China and India can narrow this Internet digital divide by effectively exploiting the Internet in their countries.

\section{Economic Development}

Economic development and the digital divide go hand-in-hand for many reasons. Communities with tools and skills to compete in digital economy are at distinct advantage over communities that don't. A community with a well-educated, technology-literate population is more likely to attract and sustain new businesses, and which in turn attract well-educated, technology-literate people into the area. Conversely, a community that lacks reliable access to technology and the skills to use it is less likely to attract and sustain new businesses that could potentially serve as a catalyst to economic prosperity. Simply put, if communities are to remain competitive in attracting, retaining and developing businesses in today's economy, they must develop modern telecommunications facilities and cultivate a well-trained workforce to stay viable.

Two critical success factors for, that should be kept track of, transcending the digital divide is adequate funding and good planning. Although, it is too early to make any firm conclusions about the overall nature of a desired future digital society, as these subjects are in a constant state of definition, redefinition and evolution, present state of knowledge illustrates some important, basic, approaches.

- Social inclusion.

- Effective and efficient use of IT\& human resources.

- Building services around citizens' choices

- Providing information responsibly 
- Making government and its services more accessible online.

\section{Some Facts}

Electronic readiness of a country is another critical success factor for digital divide. E-readiness assessment is a major international assessment of countries' capacity to exploit the opportunities offered by ICTs and helps to map out the factors \& the deficiencies that contribute to this capacity. Such assessments are momentous in the case of countries like India where statistics on one hand shows that Indian IT professionals are most sought after in the world and India is among the largest software solution providers whereas on the other hand, approx. 50 percent of the population has not even seen the computer. Over the past few years, a number of electronic readiness assessments have been carried out. In fact, India has been assessed 11 times at the global level. Some of them are given below:

- The July 2002 EIU ranking ranks India below SriLanka at 43rd out of 60 as E-business follower.

- The January 2001 IDC ranking found that 55 of the countries navigating the information Super highway account for 98 per cent of all IT in 150 countries. It ranked India at 54 and Pakistan at 55 among the group of elite 55 .

- The May 2001, Mc-Connell ranking of EReadiness Assessment indicated that substantial improvements were needed in the area of Connectivity. Improvements are also required in the areas of ELeadership, E-Business, Information security and Human Capital.

- The Global Information Technology report, 200203, ranked India 37, above China which is ranked 43rd, where as the 2001-02 report ranked India 54.

The enabling factors are constructed to reflect the preconditions for quality network infrastructure as well as future network proliferation and use in the country. The enabling factors are constituted of

- Information Infrastructure and Hardware and software support

- $\quad$ ICT policy of a country and Business \& Economic Environment.

- Networked Society

- Networked Economy that is e-commerce, egovernment and general infrastructure.

Networked society assesses quality of learning using information and communication technologies, the extent of their use and societal and demographic factors. Networked Economy considers the extent to which the public and private sectors are participating in the networked world.

\section{Role of Private Sector}

About using Knowledge Management as an approach for finding appropriate information in a work situation in Knowledge Intensive Industry is the ability to find appropriate information in a work situation is a
Knowledge Intensive activity that is relevant to Knowledge Management. Modern Knowledge Management increasingly adopts knowledge sharing approaches, such as communities of practice, commercial information technology that is to support knowledge management tends to draw on Electronic Service for knowledge management.

Organisations are incessantly looking for means to stimulate innovation and creativity, within and across work groups, functions and geographical boundaries. One of the ways to achieve this is through tacit knowledge exchanges in the form of sharing and transfer of knowledge by means of narratives, storytelling, reminders, best practices etc. At the same time, organisations are turning more towards information technology and seek ways of leveraging their investments in Information and Communication Technologies, Web technologies, in particular, to foster knowledge exchanges between individuals and work groups. The Web may be applied in new, innovative ways to draw dispersed community members together virtually and in particular, to promote tacit knowledge exchanges

The importance of industrial contribution can be reckoned by studying the case of an Indian company ITC's International Business Division, which in 6000 villages, creates e-choupals where they use computers and the internet to conduct their business. The target product is wheat and if ITC manages to capture the value of this wheat over next couple of months through these echoupals, it will be a step closer to its dream of being India's largest agri-produce processor which services 100,000 villages covering 10 million farmers by 2007.The more audacious game plan of ITC is to create " An information superhighway to connect the rural economy". That means using the e-choupals as a single point of contact between farmers and a range of suppliers of agri-inputs and consumer goods - Monsanto, Eicher, Nagarjuna Fertilizers, et al.

To start with, choupal is a village square in north India where people gather to exchange gossip, to watch $\mathrm{TV}$, talk work and the weather, etc. before they finally head home. These quaint trends are enabled with a PC, and provided an Internet access is termed as e-choupal with a business model build around. ITC started with these e-choupals to gain control over soyabean market and traded soyabean worth Rs 1600 million during last year. For its business models success, ITC created soya processing and collection centre. Then it started scouting villages around these centres for lead farmers to lead choupals. The computer was placed at this lead farmer's house and he was trained to use it. The information on daily prices was made available through Internet, at lead farmer's house. Information regarding best practices in farming and weather forecasts are also supplied. Coordinators were created who were responsible for market documentation, supplies farm inputs from ITC to lead farmers and build relations with and within lead farmers. 
The concept is being picked out as evidence of how corporations can smartly fill institutional voids in emerging markets using power of Information Technology. This experiment creates enough communication capacity to connect with a market segment that is currently underserved but clearly has purchasing power. In the end, the rural India is the beneficiary by two ways, firstly by getting good yields for the crops and secondly knowing the power of IT and Internet. The concept is related rightly to the roots of those who till date were earning the least advantage of the ICTs.

This community-centric model of ITC (Fig. 1) not only instigates the rural economy through the means of Internet but paved the way for those who were lacking due to the unawareness of the use of Information super highway. Indirectly, this also creates inquisitiveness to learn more about the dominance of ICTs.
- The fundamental reengineering and streamlining of the structures of government and the nature of public administration;

- The use of ICTs to foster new levels of democracy and citizen engagement, from electronic town halls to the online voting booth and new levels of political accountability.

\section{References}

[1] Geoffrey S. Kirkman, Carlos A. Osorio \& Jeffrey D. Sachs, "The Networked Readiness Index: Measuring the Preparedness of Nations for the Networked World", Center for International Development (CID), Harvard University, 2002.

[2] Yoo Soo Hong, Narrowing the Digital Gap in the APEC Region, Korea Institute for International Economic Policy, 2002.

[3] Nikhil Agarwal \& A.M Sherry, "Knowledge Economy: A Strategic Economic Transformation”, Paradigm, 2001.

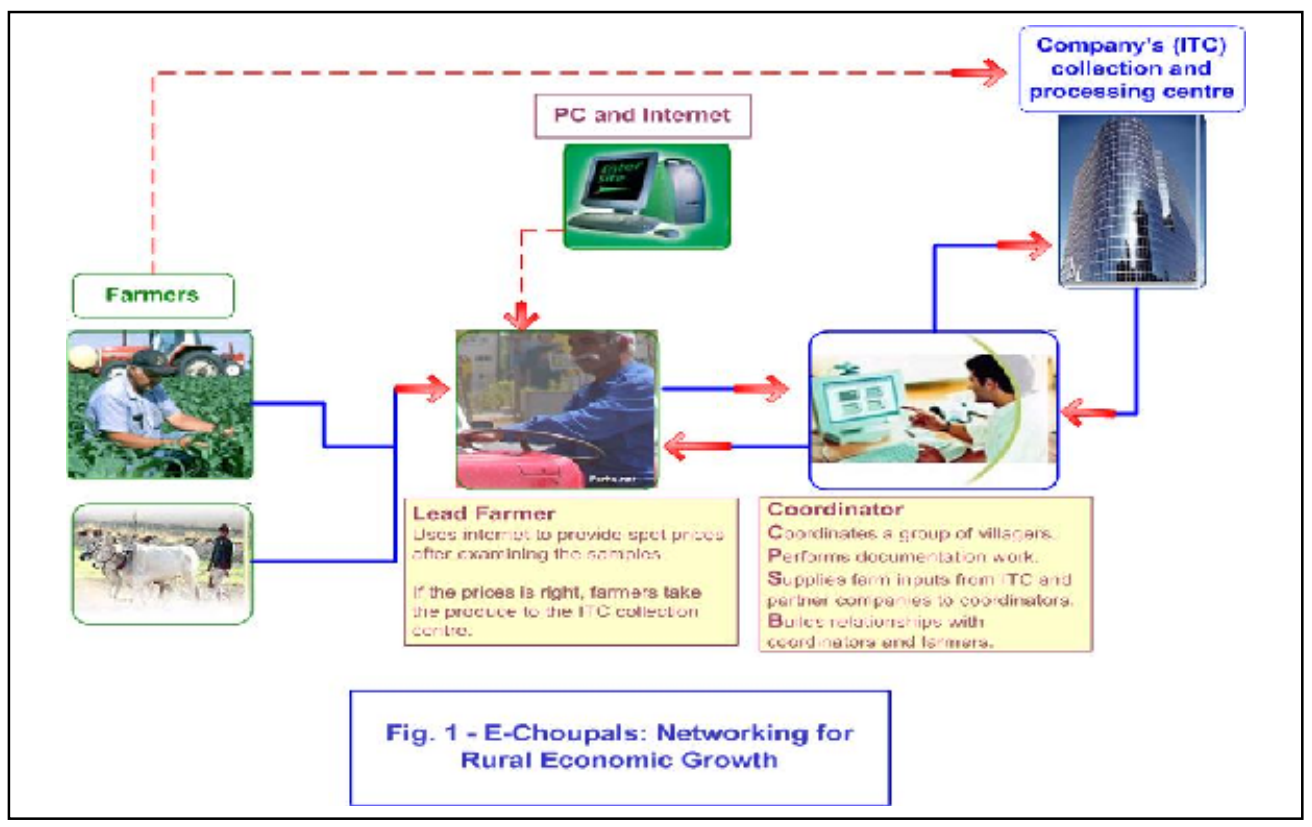

\section{Conclusion}

As a composite of the application of technology to government and bridge the digital gap, the solution falls beneath a large technological umbrella that includes:

- Instigating policies to promote private sector to participate and promote programmes that support the enlistment of digital society.

- The automation of public systems and the online delivery of services.

- The widespread adoption of network-based technologies and the migration to the Internet environment;

- the application of electronic capabilities and practices to governmental environments, to reduce costs and client fraud and to increase efficiency;

- The use of information and communication technologies (ICTs) to facilitate the conduct of business and foster economic growth;
[4] Mohan Sawhney, "E-Governance towards the next generation", Kellogg School of Management, 2001.

[5] Dr. Hongren Zhou, Global Perspectives on E-Government, International _ _ _ tracking _ _ _ survey report, inttp://www.unpan.org/e-government/ZhouEgovUNPAN_files/frame.htm, $200 \overline{1}$.

[6] World Development Report, 2002.

[7] Stefan Thomke and Eric Von Hippel, "Customers as Innovators: A new way to create value", Harward Business Review, April 2002, pg. 74-81

[8] Charles Assisi and Indrajit Gupta, "ITC's Rural Symphony", Business World, Jan. 2003, pg.30-35.

Note: The full paper is available from the CD of conference proceedings. 